\title{
KETIMPANGAN PENDAPATAN DAN POTENSI SEKTORAL DI KALIMANTAN TIMUR TAHUN 2002-2004
}

\author{
Oleh: Mayahayati Kusumaningrum 7
}

\begin{abstract}
One of common characteristics of the less-developed countries is widespread of economic inequality among their regions. The problem of regional disparity occurs due to differentiation of both quality and quantity of human and natural resources. Indonesia is a classic example of a country with deep economic gap among its provinces. Ironically, East Kalimantan as one of the richest provinces in Indonesia has experienced the similar case. The development of Cities is approximately faster than that of Districts. Such situation is contributed by some factors such as concentration of economic activities, uneven distribution of investment, mobility rate of production, deprived domestic and international trade, etc. The implementation of policy on regional autonomy is intended to minimize such development upheaval. To some extent, however, autonomy laws have been sharpening the disparity among regions, particularly between oil-and-gas-based-regions and non-oiland-gas-based-regions. It means that natural resource (i.e. oil and gas) industry plays crucial role in escalating local development, especially where third sector (services, technology-based, communication, etc) is poorly developed. In the long-term perspective, the dependency on natural resource which is nonrenewable should be shifted to other sector having the potency to be continuously renewed. By using affiliation from Location Quotient (LQ) analysis, this paper tries to excavate the potency and inequality of economic development in East Kalimantan Province. The analysis aims to identify the priority of sound development sector in certain area and finding out the area owning advantage of location from any sector, in order to improve efficiency of economic activities.
\end{abstract}

Keywords: ketimpangan ekonomi/pendapatan, sektor potensial, Kalimantan Timur.

\section{Latar Belakang}

Pembangunan nasional merupakan rangkaian upaya pembangunan yang berkesinambungan yang meliputi seluruh kehidupan masyarakat, bangsa dan negara untuk melaksanakan tugas mewujudkan pembangunan nasional yang termaktub dalam pembukaan

\footnotetext{
Mayahayati Kusumaningrum, SE adalah Staf Peneliti bidang Kajian Aparatur pada Pusat Kajian dan Pendidikan dan Pelatihan Aparatur III Lembaga Administrasi Negara, Samarinda.
} 
UUD 1945. Dalam proses pembangunan, selain mempertimbangkan aspek pertumbuhan pemerataan juga mempertimbangkan dampak aktivitas ekonomi terhadap kehidupan sosial masyarakat. Menurut Sukirno (1985: 13), pembangunan ekonomi tersebut menjadi proses yang menghasilkan peningkatan pendapatan per kapita penduduk suatu negara dalam jangka panjang.

Sasaran pembangunan nasional di Indonesia diantaranya untuk mencapai tingkat pertumbuhan ekonomi yang tinggi, menyebarluaskan hasil-hasil pembangunan secara seimbang di berbagai daerah, serta dalam rangka membangun manusia Indonesia seutuhnya. Dengan terciptanya konsep pembangunan yang demikian diharapkan dapat meletakkan landasan yang bagi bangsa Indonesia untuk tumbuh dan berkembang atas kemampuan sendiri. Dalam upaya mencapai sasaran pembangunan diatas, diperlukan kebijaksanaan pembangunan. Kebijaksanaan pembangunan dijabarkan dalam kebijaksanaan bidang secara umum dan kebijaksanaan sektoral, dimana salah satu kebijaksanaan bidang secara umum adalah bidang ekonomi.

Menurut Badan Pusat Statistik, bidang ekonomi meliputi: (1) Pertanian, Peternakan, Kehutanan dan Perikanan, (2) Pertambangan dan Penggalian, (3) Industri Pengolahan, (4) Listrik, Gas dan Air Bersih, (5) Bangunan, (6) Perdagangan, Hotel dan Restoran, (7) Pengangkutan dan Komunikasi, (8) Keuangan, Persewaan dan Jasa Perusahaan, serta (9) Jasa-jasa.

Laju pertumbuhan ekonomi pada hakekatnya merupakan ukuran mengenai besarnya kemampuan suatu negara untuk menghasilkan barang dan jasa dalam suatu tahun tertentu yang dinyatakan dalam Produk Domestik Bruto (PDB) untuk tingkat nasional dan Produk Domestik Regional Bruto (PDRB) untuk tingkat daerah, dimana data tersebut dapat digunakan untuk (a) menilai prestasi pertumbuhan ekonomi dan (b) menentukan tingkat kemakmuran masyarakat dan perkembangannya. Dari pengertian diatas tampak bahwa tolak ukur adanya pembangunan ekonomi adalah terjadinya pertumbuhan ekonomi, yaitu apabila tingkat kegiatan ekonomi lebih tinggi dari yang dicapai pada masa sebelumnya. (Sukirno, 1985: 19)

Ditinjau dari Produk Domestik Regional Bruto, tiap-tiap daerah memiliki tingkat pertumbuhan yang tidak sama atau bervariasi karena masing-masing daerah mempunyai perbedaan kuantitas dan kualitas sumber daya manusia yang didukung oleh kondisi geografis dan sumber daya alam yang berbeda pula. Apalagi sejak dikeluarkannya Undang-Undang Nomor 22 Tahun 1999 yang telah diperbaharui dengan UU Nomor 32 Tahun 2004 tentang Pemerintahan Daerah yang menyebabkan kewenangan daerah untuk untuk menggali potensi daerahnya semakin besar sehingga daerah dapat berkompetisi dalam melakukan pembangunan di daerahnya sehingga akan terjadi percepatan pembangunan di masing-masing daerah. Jadi dengan kebijakan otonomi ini diharapkan dapat menjadi solusi ampuh dalam mengatasi persoalan kesenjangan sektoral maupun kesenjangan regional. Namun dalam penerapannya, apabila kebijakan otonomi tidak hati-hati dan/atau "selfish", justru akan mengancam dan menyebabkan kesenjangan/ ketimpangan ekonomi yang lebih parah. Tingkat pertumbuhan yang tidak sama antar daerah justru malah meyebabkan ketimpangan.

Ketimpangan ini perlu diperhatikan karena keberhasilan suatu pembangunan tidak hanya 
diukur dari tingkat pendapatan riil per kapita atau laju pertumbuhan output yang tinggi, tetapi yang harus dilihat apakah pembangunan selama ini relatif merata.

Menurut Williamson, pada tingkat awal pembangunan terjadi ketimpangan pendapatan regional yang makin meningkat. Dalam hal ini ketimpangan akan makin menurun secara otomatis bersamaan dalam proses perekonomian yang sudah matang. Faktor-faktor penyebab terjadinya ketimpangan antar daerah yang semakin besar, yaitu: konsentrasi kegiatan ekonomi wilayah, alokasi investasi, tingkat mobilitas faktor produksi yang rendah antar daerah, perbedaan sumber daya alam (SDA) antar daerah, perbedaan kondisi demografis antar daerah dan kurang lancarnya perdagangan antar daerah. (Tambunan, 2001: 278-286)

Pada dasarnya proses perencanaan pembangunan yang dilakukan berjalan dua arah, yaitu dari atas ke bawah (top-down) dan dari bawah ke atas (bottom-up) (Kartasasmita, 1996: 336-337). Dari atas ke bawah berupa penetapan sasaran-sasaran makro dan sektoral serta kebijaksanaan-kebijaksanaan pembangunan secara nasional. Dari bawah ke atas berupa aspirasi daerah yang merencanakan pengembangan potensi daerah serta menampilkan keadaan yang nyata di lapangan.

Sektor-sektor dalam kegiatan ekonomi memegang peranan penting dalam perencanaan karena data-data yang diperlukan dalam perencanaan berasal dari sektor-sektor ekonomi tersebut. Untuk mempercepat laju pertumbuhan ekonomi daerah perlu dikembangkan sektor-sektor ekonomi yang memiliki pertumbuhan yang cepat dalam pembentukan PDRB daerah bersangkutan.

Menurut Kadariah (1985: 13), sektor-sektor dalam perekonomian mempunyai laju perkembangan yang berbeda-beda, dan hal ini mengakibatkan terjadinya perubahan struktur ekonomi di suatu daerah. Struktur ekonomi berpengaruh pada pertumbuhan ekonomi daerah dan karena struktur ekonomi terbentuk dari berbagai sektor ekonomi maka diperlukan adanya pergeseran sumber-sumber dari sektor ekonomi yang perkembangannya lambat ke sektorsektor lainnya yang dapat berkembang lebih cepat.

Kalimantan Timur merupakan propinsi yang memiliki karakteristik perekonomian sangat terbuka dengan kabupaten/kota diantaranya Kabupaten Pasir, Kabupaten Kutai Barat, Kabupaten Kutai Kartanegara, Kabupaten Kutai Timur, Kabupaten Berau, Kabupaten Malinau, Kabupaten Bulungan, dan Kabupaten Nunukan sedangkan daerah Kota adalah Balikpapan, Samarinda, Tarakan, serta Bontang. Pada tahun 2002, Pemerintah Kabupaten Penajam Paser Utara dibentuk melalui UU No 7 Tahun 2002 tanggal 10 April 2002 tentang pembentukan Kabupaten Penajam Paser Utara sebagai Kabupaten ke-13 di Propinsi Kalimantan Timur. Luas wilayah Kalimantan Timur adalah 208.657,74 km² dimana Malinau sebagai wilayah terluas sejumlah 19,07\% sedangkan yang terkecil adalah Kota Bontang dengan hanya 0,2\% dari luas wilayah Kalimantan Timur namun kepadatan penduduk di Malinau hanya sebesar 1,19 penduduk per $\mathrm{km}_{2}$ sedangkan Bontang mencapai 273,21 penduduk per $\mathrm{km}_{2}$. Data diatas menunjukkan bahwa kepadatan penduduk Kota jauh lebih tinggi/besar dibanding daerah Kabupaten, dan ini tentunya tidak lepas dari pengaruh aktivitas ekonomi dengan sarana dan prasarana yang lebih lengkap di Kota dibanding Kabupaten.

Perkembangan pembangunan di Kalimantan Timur-pun saat ini dapat dikatakan cukup berhasil dimana kontribusi PDRB Kalimantan Timur sangat besar terhadap pendapatan nasional. Laju pertumbuhan PDRB pada tahun 2004 mencapai 1,79\% sedangkan bila tanpa migas mencapai $6,98 \%$. Akselerasi pertumbuhan tersebut tentunya ditopang oleh kontribusi 
dari tiap-tiap kabupaten/kota. Tentunya kontribusi PDRB masing-masing kabupaten dan kota di Kalimantan Timur itu berbeda-beda. Jika dilihat berdasar nilai PDRB masing-masing kabupaten/kota terlihat bahwa Kota Bontang dan kabupaten Kutai Kartanegara memiliki kontribusi yang paling besar pada PDRB Kalimantan Timur sedangkan kabupaten Nunukan dan Malinau memiliki kontribusi yang kecil.

\section{Tabel 1}

PDRB Kalimantan Timur Menurut Kabupaten/Kota Tahun 2002 dan 2004

Atas Dasar Harga Konstan 2000

\begin{tabular}{|c|c|c|c|}
\hline \multirow{2}{*}{ No } & \multirow{2}{*}{ KABUPATEN/KOTA } & \multicolumn{2}{|c|}{ PDRB (dalam juta) } \\
\hline & & 2002 & 2004 \\
\hline 1 & Kabupaten Pasir & $2,339,469$ & $2,603,641$ \\
\hline 2 & Kabupaten Kutai Barat & $1,887,883$ & $2,243,830$ \\
\hline 3 & Kabupaten Kutai Kartanegara & $21,405,448$ & $23,320,488$ \\
\hline 4 & Kabupaten Kutai Timur & $7,727,871$ & $9,220,373$ \\
\hline 5 & Kabupaten Berau & $2,358,136$ & $2,544,576$ \\
\hline 6 & Kabupaten Malinau & 423,234 & 473,726 \\
\hline 7 & Kabupaten Bulungan & 886,314 & 935,347 \\
\hline 8 & Kabupaten Nunukan & 935,903 & $1,023,402$ \\
\hline 9 & Kota Balikpapan & $11,996,137$ & $12,917,884$ \\
\hline 10 & Kota Samarinda & $7,204,785$ & $8,601,032$ \\
\hline 11 & Kota Tarakan & $1,495,387$ & $1,695,398$ \\
\hline 12 & Kota Bontang & $27,055,605$ & $26,435,546$ \\
\hline \multirow[t]{2}{*}{13} & Kabupaten PPU & 684,462 & 814,878 \\
\hline & JUMLAH & $86,400,634$ & $92,830,121$ \\
\hline
\end{tabular}

Sumber: Badan Pusat Statistik, data disusun kembali.

Besarnya PDRB yang berbeda-beda ini karena kontribusi tiap-tiap sektor di masingmasing daerah yang tidak sama. Hal ini berkaitan dengan potensi yang dimiliki masingmasing kabupaten/kota baik berupa sumber daya alam, sumber daya manusia, maupun kondisi geografis yang berbeda-beda. Perbedaan PDRB tersebut menyebabkan pula disparitas percepatan perkembangan pembangunan di kabupaten/kota tersebut. Daerah perbatasan 
seperti Nunukan, Malinau dan Kutai Barat memiliki PDRB yang relatif kecil sementara kabupaten/kota lainnya pembangunannya justru semakin cepat.

Sehubungan dengan latar belakang yang dikemukakan di atas sangatlah penting bahwa di dalam melakukan perencanaan pembangunan di suatu daerah, pemerintah hendaknya juga memperhatikan potensi serta kondisi regional suatu daerah. Dengan berdasar PDRB tahun 2002-2004 ini berupaya dicari gambaran sektor potensial di kabupaten/kota Kalimantan Timur.

\section{Analisis Ketimpangan Pendapatan Antar Daerah}

Untuk menganalisis permasalahan diatas, pertama kali akan dideteksi ketimpangan antar kabupaten/kota dengan melihat nilai PDRB per kapita kemudian digunakan analisis LQ. Analisis ini digunakan untuk mengidentifikasi sektor unggulan di masing-masing kabupaten/kota. Analisis berikutnya yang digunakan untuk mengevaluasi perubahan relatif dan perubahan struktural suatu daerah adalah analisis shiftshare.

Untuk melihat ketimpangan pendapatan disini digunakan PDRB per kapita dari masing-masing Kabupaten/Kota di Kalimantan Timur. Data yang digunakan adalah PDRB per kapita atas dasar harga konstan 2000 di Kalimantan Timur. Dengan menggunakan nilai PDRB per kapita dengan dan tanpa migas dimaksudkan untuk mengetahui seberapa besar migas berpengaruh pada ketimpangan pendapatan antar kabupaten/kota.

Tabel 2

PDRB Per Kapita Kabupaten/Kota di Kalimantan Timur Dengan Migas Tahun 2002-2004 Atas Dasar Harga Konstan 2000

\begin{tabular}{|c|c|c|c|c|}
\hline \multirow{2}{*}{ No } & \multirow{2}{*}{$\begin{array}{l}\text { KABUPATEN/ } \\
\text { KOTA }\end{array}$} & \multicolumn{3}{|c|}{ PDRB per kapita (juta) } \\
\hline & & 2002 & 2003 & 2004 \\
\hline 1 & Kabupaten Pasir & 13.76708919 & 14.24561891 & 15.15745199 \\
\hline 2 & Kabupaten Kubar & 13.28222970 & 17.46788339 & 15.21570781 \\
\hline 3 & Kabupaten Kukar & 47.69294417 & 45.54035492 & 48.04633119 \\
\hline 4 & Kabupaten Kutim & 48.73168748 & 45.82574030 & 54.77850654 \\
\hline 5 & Kabupaten Berau & 18.00268727 & 18.41420389 & 18.08113351 \\
\hline 6 & Kabupaten Malinau & 11.02171875 & 9.60834368 & 10.02424986 \\
\hline 7 & $\begin{array}{l}\text { Kabupaten } \\
\text { Bulungan }\end{array}$ & 10.30334101 & 9.55147836 & 9.68288163 \\
\hline 8 & Kabupaten Nunukan & 10.99523021 & 9.52627939 & 9.57210868 \\
\hline 9 & Kota Balikpapan & 28.47206940 & 28.59441862 & 29.96403263 \\
\hline 10 & Kota Samarinda & 13.24301895 & 14.05371426 & 15.14274195 \\
\hline
\end{tabular}




\begin{tabular}{|l|l|l|l|l|}
11 & Kota Tarakan & 12.54308841 & 11.15470708 & 11.13203632 \\
& & 255.9756755 & 237.9893528 & 227.3008718 \\
12 & Kota Bontang & 2 & 7 & 7 \\
13 & Kabupaten PPU & 6.12532329 & 6.47779762 & 6.89295291 \\
\hline & Perkapita prop & $\mathbf{3 7 . 7 0 4 3 1 5 6 4}$ & $\mathbf{3 6 . 0 3 4 6 0 7 1 8}$ & $\mathbf{3 6 . 2 3 0 0 7 7 4 5}$ \\
\hline
\end{tabular}

Nilai PDRB per kapita dengan migas menunjukkan bahwa Kota Bontang memiliki PDRB per kapita yang jauh lebih tinggi dibandingkan dengan PDRB per kapita propinsi Kalimantan Timur dan kabupaten/kota lainnya. PDRB per kapita Kota Bontang sangat tinggi dikarenakan besarnya kontribusi gas alam sektor industri pengolahan (migas) pada PDRB Kota Bontang. Hal ini jauh berbeda bila sector migas dikeluarkan maka meskipun PDRB per kapita Kota Bontang lebih tinggi daripada PDRB per kapita propinsi Kalimantan Timur namun selisihnya tidak terlalu besar bahkan masih berada di bawah PDRB per kapita Kabupaten Kutai Timur yang nilainya stabil baik dengan dan tanpa migas, daerah lainnya yang juga berpengaruh bila migas tidak dimasukkan adalah Kabupaten Kutai Kartanegara dan Kota Balikpapan.

Tabel 3

PDRB Per Kapita Kabupaten/Kota di Kalimantan Timur Tanpa Migas Tahun 2002-2004 Atas Dasar Harga Konstan 2000

\begin{tabular}{|c|c|c|c|c|}
\hline \multirow{2}{*}{ No } & \multirow{2}{*}{$\begin{array}{l}\text { KABUPATEN/ } \\
\text { KOTA }\end{array}$} & \multicolumn{3}{|l|}{ IW } \\
\hline & & 2002 & 2003 & 2004 \\
\hline 1 & Kabupaten Pasir & 13.7670892 & 14.2456189 & 15.1574520 \\
\hline 2 & Kabupaten Kubar & 13.2822297 & 17.4678834 & 15.2157078 \\
\hline 3 & Kabupaten Kukar & 11.4580094 & 11.7100431 & 12.5998063 \\
\hline 4 & Kabupaten Kutim & 47.1815235 & 44.3073452 & 53.2260859 \\
\hline 5 & Kabupaten Berau & 18.0026873 & 18.4142039 & 18.0811335 \\
\hline 6 & Kabupaten Malinau & 11.0217188 & 9.6083437 & 10.0242499 \\
\hline 7 & Kabupaten Bulungan & 8.9506173 & 8.2812487 & 8.3902255 \\
\hline 8 & Kabupaten Nunukan & 6.5758761 & 5.7426906 & 8.9066268 \\
\hline 9 & Kota Balikpapan & 13.9094344 & 15.0156779 & 15.5548267 \\
\hline 10 & Kota Samarinda & 13.2430189 & 14.0537143 & 15.1427420 \\
\hline 11 & Kota Tarakan & 11.8500839 & 10.6487773 & 10.7237802 \\
\hline
\end{tabular}




\begin{tabular}{|l|l|l|l|l|}
12 & Kota Bontang & 20.6075727 & 18.4681028 & 17.9742739 \\
13 & Kabupaten PPU & 6.1253233 & 6.4777976 & 6.8929529 \\
\hline & Perkapita prop & $\mathbf{1 5 . 0 7 5 0 1 4 2}$ & $\mathbf{1 4 . 9 5 7 0 3 4 4}$ & $\mathbf{1 5 . 9 9 1 5 2 7 9}$ \\
\hline
\end{tabular}

\section{Teori Basis Ekonomi dan Analisis Location Quotient}

Menurut Glasson (1976: 65), perekonomian regional dapat dibagi menjadi dua sektor, yaitu kegiatan basis dan kegiatan bukan basis. Kegiatan basis (basic activities) adalah kegiatan yang mengekspor barang-barang dan jasa-jasa ke tempat-tempat di luar batas-batas perekonomian masyarakat yang bersangkutan, atau yang memasarkan barang-barang dan jasa-jasa mereka kepada orang-orang yang datang dari luar perbatasan perekonomian masyarakat yang bersangkutan. Sedangkan kegiatan-kegiatan bukan basis (non basic activities) adalah kegiatan-kegiatan yang menyediakan barang-barang yang dibutuhkan oleh orang-orang yang bertempat tinggal di dalam batas-batas perekonomian masyarakat yang bersangkutan. Kegiatan-kegiatan ini tidak mengekspor barang-barang jadi; luas-lingkup produksi mereka dan daerah pasar mereka yang terutama adalah bersifat lokal.

Beberapa metode yang dilakukan untuk membagi sektor-sektor dalam kategori basis dan bukan basis, salah satunya menyebutkan metode Location Quotient. Location Quotient adalah suatu teknik untuk mengukur konsentrasi suatu kegiatan ekonomi atau sektor di suatu daerah dengan cara membandingkan peranannya dalam perekonomian daerah tersebut dengan peranan dari kegiatan ekonomi atau sektor yang sama pada tingkat nasional" (Tambunan, 2001: 293).

Perhitungan LQ ini didasarkan pada nilai tambah (PDRB) suatu sector tertentu yang dirumuskan sebagai berikut:

$$
\mathrm{LQ}_{\mathrm{i}}{ }^{j}=\frac{\mathrm{VA}_{\mathrm{i}} \mathrm{PDORB}_{j}}{\mathrm{VA}_{i}{ }^{\mathrm{P}} \mathrm{P} \mathrm{DRB}_{\mathrm{i}}}
$$

Dimana $L Q_{j} \quad=L Q$ sektor I di kabupaten/kota $\mathrm{j}$

$$
\begin{aligned}
& \mathrm{VA}_{\mathrm{ij}}=\text { nilai tambah sektor I di kabupaten/kota } \mathrm{j} \\
& \mathrm{VA}_{\mathrm{i}} \mathrm{I}=\text { nilai tambah sektor I di propinsi Kalimantan Timur } \\
& \mathrm{PDRB}_{\mathrm{j}}=\mathrm{PDRB} \text { di kabupaten/kota } \mathrm{j} \\
& \mathrm{PDRB}_{\mathrm{I}}=\text { PDRB di propinsi Kalimantan Timur }
\end{aligned}
$$

Berdasar perhitungan tersebut angka LQ ini memberikan indikasi sebagai berikut:

a. Jika $\boldsymbol{L} \boldsymbol{Q}<\mathbf{1}$, maka daerah tersebut dikategorikan daerah non basis dimana industrinya hanya mampu memasarkan produksi di daerah yang bersangkutan, hanya menunjukkan kegiatan local, tidak cocok untuk kegiatan industri. 
b. Jika $\boldsymbol{L} \boldsymbol{Q}>\boldsymbol{1}$, maka daerah tersebut dikategorikan daerah basis, dapat mengekspor produksinya ke daerah lain.

c. Jika $\boldsymbol{L} \boldsymbol{Q}=\mathbf{1}$, maka daerah tersebut telah menghasilkan produksi industri dalam perekonomian kabupaten/kota.

Melalui pendekatan sektoral, pembangunan lebih dititikberatkan pada pencapaian pertumbuhan ekonomi yang setinggi-tingginya dengan memberikan prioritas pembangunan pada sektor-sektor yang potensial untuk berkembang. Peningkatan pada sektor-sektor yang dapat tumbuh dengan cepat ini selain dapat meningkatkan pertumbuhan ekonomi, diharapkan juga akan mendorong perkembangan sektor lain yang belum maju.

\section{Tabel 4}

Indeks Location Quotient Sektor-Sektor PDRB Kabupaten/Kota Kalimantan Timur Tahun 2002-2004 Atas Dasar Harga Konstan 2000

\begin{tabular}{|c|c|c|c|c|c|c|c|c|c|c|}
\hline \multirow[t]{2}{*}{ NO } & \multirow{2}{*}{$\begin{array}{l}\text { KABUPATEN/ } \\
\text { KOTA }\end{array}$} & \multicolumn{9}{|c|}{ SEKTOR } \\
\hline & & 1 & 2 & 3 & 4 & 5 & 6 & 7 & 8 & 9 \\
\hline 1 & Kab.Pasir & 3.41243 & 1.89332 & 0.05961 & 0.64429 & 0.66535 & 0.35223 & 0.39591 & 0.78908 & 1.26395 \\
\hline 2 & Kab.Kubar & 3.61006 & 1.42155 & 0.05464 & 0.66766 & 3.07467 & 0.79610 & 0.47708 & 1.07055 & 1.41596 \\
\hline 3 & Kab.Kukar & 1.34841 & 2.38899 & 0.06038 & 0.22301 & 0.80915 & 0.36278 & 0.22316 & 0.38027 & 0.45826 \\
\hline 4 & Kab.Kutim & 0.92585 & 2.48344 & 0.01198 & 0.28970 & 0.80188 & 0.41216 & 0.53623 & 0.53540 & 0.39756 \\
\hline 5 & Kab.Berau & 3.55739 & 1.12509 & 0.38371 & 0.39055 & 0.28009 & 1.39320 & 2.38758 & 0.27941 & 1.27969 \\
\hline 6 & Kab.Malinau & 8.74236 & 0.33055 & 0.00156 & 0.71240 & 2.05116 & 1.82556 & 0.56183 & 0.04773 & 1.51715 \\
\hline 7 & Kab.Bulungan & 4.67921 & 0.42513 & 0.66128 & 2.54266 & 0.05744 & 1.70041 & 1.82913 & 0.14382 & 2.54881 \\
\hline 8 & Kab.Nunukan & 5.58450 & 1.21525 & 0.00095 & 1.91090 & 1.83863 & 0.88676 & 0.74117 & 0.07617 & 1.67921 \\
\hline 9 & $\begin{array}{l}\text { Kota } \\
\text { Balikpapan }\end{array}$ & 0.39463 & 0.17857 & 1.15402 & 2.02095 & 2.09633 & 2.66694 & 2.60747 & 1.09656 & 1.09122 \\
\hline 10 & Kota Samarinda & 0.34330 & 0.15813 & 0.69928 & 4.68489 & 1.24975 & 2.45394 & 3.63394 & 5.68959 & 5.27019 \\
\hline 11 & Kota Tarakan & 1.74711 & 0.16371 & 0.30474 & 5.06331 & 1.00017 & 4.60825 & 3.28202 & 3.90464 & 1.74362 \\
\hline 12 & Kota Bontang & 0.01689 & 0.00476 & 2.44663 & 0.09901 & 0.56613 & 0.14580 & 0.10284 & 0.19067 & 0.11069 \\
\hline 13 & Kab.PPU & 3.62417 & 0.01693 & 0.00764 & 0.99496 & 0.86370 & 6.566242 & 0.61400 & 1.95632 & 1.56488 \\
\hline
\end{tabular}

Dari tabel 4 diatas dapat dilihat bahwa yang menjadi sektor basis di kabupaten Pasir adalah sektor pertanian, pertambangan dan penggalian, jasa. Sektor basis di Kutai Barat adalah sektor pertanian, pertambangan dan penggalian, sektor bangunan, keuangan, persewaan, jasa perusahaan dan sektor jasa. Kutai Kartanegara dengan sektor pertanian dan 
sektor pertambangan dan penggalian. Kutai Timur dengan sektor pertambangan dan penggalian. Sektor pertanian, sektor pertambangan dan penggalian, sektor perdagangan, hotel dan restoran, sektor pengangkutan dan komunikasi dan sektor jasa menjadi sektor basis di Berau sedangkan untuk kabupaten Malinau, sektor basisnya adalah sektor pertanian, bangunan, perdagangan, hotel dan restoran dan sektor jasa. Kabupaten Bulungan memiliki sektor basis pertanian, listrik, gas dan air bersih, sektor perdagangan, hotel dan restoran, pengangkutan dan komunikasi dan sektor jasa.

Selanjutnya, sektor basis Nunukan adalah pertanian, pertambangan dan penggalian, listrik, gas dan air bersih, sektor bangunan dan sektor jasa. Kota Balikpapan dengan sektor basis industri pengolahan, listrik, gas dan air bersih, bangunan, perdagangan, hotel dan restoran, pengangkutan dan komunikasi, sektor keuangan, persewaan dan jasa perusahaan dan sektor jasa.Samarinda dengan sektor basis listrik, gas dan air bersih, bangunan, perdagangan, hotel dan restoran, sektor pengangkutan dan komunikasi, sektor keuangan, persewaan dan jasa perusahaan serta sektor jasa. Sektor basis Kota Tarakan adalah pertanian, listrik, gas dan ar bersih, bangunan, perdagangan, hotel dan restoran, pengangkutan dan komunikasi, sektor keuangan, persewaan dan jasa perusahaan dan sektor jasa. Kota Bontang dengan sektor basis industri pengolahan dan PPU dengan sektor pertanian, sektor perdagangan, hotel dan restoran, keuangan, persewaan dan jasa perusahaan dan sektor jasa.

\section{Analisis Shift Share}

Menurut Tambunan (2001: 291), analisis Shift Share dapat dipergunakan untuk menentukan kinerja atau produktivitas kerja perekonomian suatu daerah dengan membandingkannya dengan daerah yang lebih besar (nasional). Teknik analisis ini bisa digunakan untuk berbagai hal yang terkait dengan masalah-masalah ekonomi regional, misalnya mengidentifikasi sumber-sumber pertumbuhan regional, juga untuk memproyeksikan pertumbuhan ekonomi regional dan sebagai alat analisis dalam riset pembangunan pedesaan. Analisis Shift Share bisa dibagi dalam dua bagian, yaitu:

\section{a. Analisis Pangsa Regional}

Analisis PR digunakan untuk melihat sektor atau posisi relatif suatu daerah. Analisis pergeseran dapat digunakan untuk mengetahui apakah pertumbuhan di daerah tersebut cenderung mendorong pertumbuhan propinsinya.

\section{b. Analisis Pergeseran}

"Analisis pergeseran merupakan metode yang lebih tepat untuk meneliti struktur ekonomi dan menganalisa perubahan sebagai indikator kegiatan ekonomi suatu daerah dibandingkan dengan menggunakan analisis PR". (Tambunan, 1996:216). Analisis pergeseran terdiri dari dua sub komponen, yaitu perubahan secara proporsional (PS) dan perubahan yang berbeda (DS). Analisis PS digunakan untuk meneliti besarnya konsentrasi regional pada sektor-sektor yang mengalami pertumbuhan tinggi atau lambat di tingkat propinsi. Suatu kabupaten/kota yang dominan pada sektor ekonomi yang tumbuh dengan cepat di tingkat propinsi maka kabupaten/kota memiliki PS positif. Sebaliknya jika suatu kabupaten/kota memiliki sektor ekonomi tertentu yang dominan tetapi sektor tersebut tumbuh relatif lambat tingkat propinsi maka kabupaten/kota tersebut akan memiliki nilai PS negatif.

Analisis DS secara sektoral digunakan untuk mengetahui pertumbuhan masing-masing sektor di tiap-tiap kabupaten/kota di Kalimantan Timur. Angka DS yang positif di suatu daerah menunjukkan bahwa sektor tersebut tumbuh lebih cepat daripada pertumbuhan sektor yang sama di tingkat propinsi, yang berarti daerah tersebut mempunyai keuntungan lokasional yang baik. Angka DS yang bernilai negatif di suatu daerah menunjukkan bahwa sektor tersebut tumbuh lebih lambat daripada pertumbuhan sektor yang sama di propinsi, 
yang berarti daerah tersebut memiliki kedudukan yang lemah. Jadi dari analisis ini dapat mencerminkan posisi bersaing kabupaten/kota di propinsi. (Tambunan, 1996: 214)

Rumusan-rumusan shift share sebagai berikut:

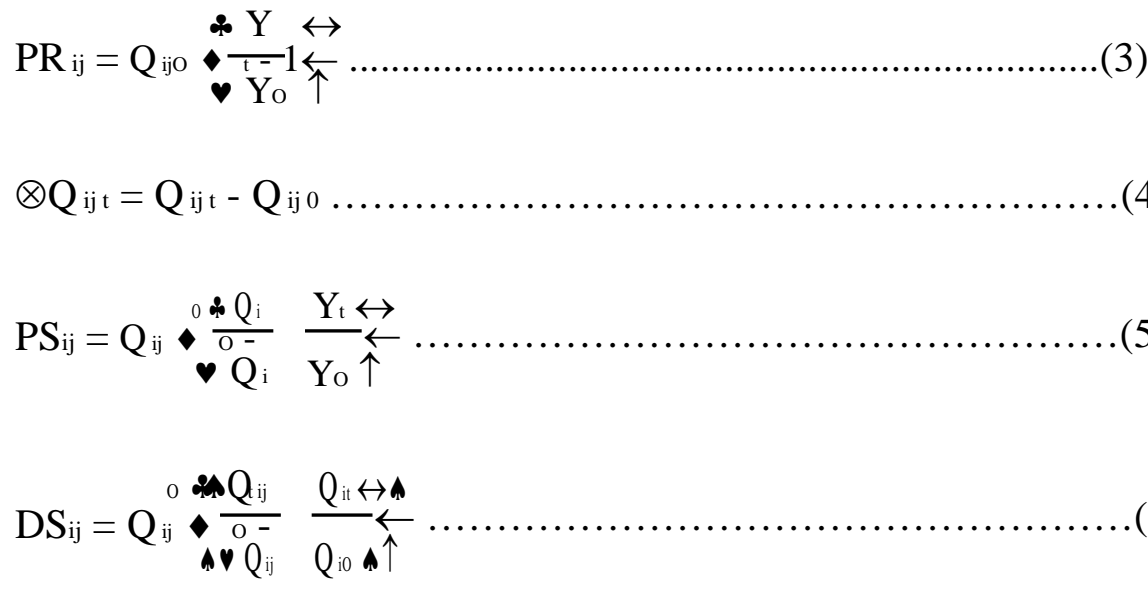

Dimana $P R_{i j}=$ pangsa regional sektor i pada kabupaten $/$ kota $\mathrm{j}$

$\mathrm{PS}_{\mathrm{ij}} \quad=\mathrm{P}$-shift sektor $\mathrm{i}$ di kabupaten/kota $\mathrm{j}$

$\mathrm{DS}_{\mathrm{ij}} \quad=\mathrm{D}$-shift sektor i di kabupaten/kota $\mathrm{j}$

$\mathrm{Q}_{\mathrm{ij} 0} \quad=$ PDRB sektor $\mathrm{i}$ pada kabupaten/kota $\mathrm{j}$ untuk periode tahun dasar

$\mathrm{Y}_{\mathrm{t}} \quad=\mathrm{PDRB}$ propinsi pada periode tahun $\mathrm{t}$

$\mathrm{Y}_{0}=\mathrm{PDRB}$ propinsi pada periode tahun dasar

$\mathrm{Q}_{\mathrm{it}} \quad=$ PDRB propinsi di sektor $\mathrm{i}$ tahun $\mathrm{t}$

$\mathrm{Q}_{\mathrm{i} 0} \quad=$ PDRB propinsi di sektor $\mathrm{i}$ tahun dasar

$\mathrm{Q}_{\mathrm{ijt}} \quad=$ PDRB sektor $\mathrm{i}$ di kabupaten/kota $\mathrm{j}$ tahun $\mathrm{t}$

Dari hasil perhitungan tersebut apabila:

c. $P S<0$, maka dikatakan di tingkat propinsi, sektor tersebut tumbuh relatif lambat.

d. $P S>0$, maka dikatakan di tingkat propinsi, sektor tersebut tumbuh relatif cepat.

e. $\boldsymbol{D S}<\boldsymbol{0}$, maka dikatakan sektor tersebut memiliki pertumbuhan yang lebih lambat dibandingkan sektor yang sama di daerah lain atau dikatakan daerah tersebut tidak memiliki keunggulan lokasional yang baik.

f. $\boldsymbol{D S}>\mathbf{0}$, maka dikatakan sektor tersebut memiliki pertumbuhan yang lebih cepat dibandingkan sektor yang sama di daerah lain atau dikatakan daerah tersebut memiliki keunggulan lokasional yang baik. 
g. $\boldsymbol{P R}<\otimes \boldsymbol{Q}_{i j}$, maka dikatakan pertumbuhan produksi di daerah tersebut cenderung mendorong pertumbuhan propinsi.

h. $\boldsymbol{P R}>\otimes \boldsymbol{Q}_{i j}$, maka dikatakan pertumbuhan produksi di daerah tersebut cenderung akan menghambat pertumbuhan propinsi.

Tabel 5

Analisa Proporsional Shift Dari 13 Kabupaten/Kota

Di Kalimantan Timur Tahun 2002-2004

\begin{tabular}{|c|c|c|c|c|c|c|c|c|c|c|c|}
\hline \multirow[t]{2}{*}{ NO } & \multirow{2}{*}{$\begin{array}{l}\text { KABUPATEN/ } \\
\text { KOTA }\end{array}$} & \multicolumn{10}{|c|}{ SEKTOR } \\
\hline & & 1 & 2 & 3 & 4 & 5 & 6 & 7 & 8 & 9 & TOTAL \\
\hline 1 & Pasir & 5850 & 62756 & -4837 & 823 & 12160 & 8939 & 1895 & -393 & 3641 & 90834 \\
\hline 2 & Kubar & 5138 & 38712 & -3476 & 621 & 41735 & 15703 & 1813 & -406 & 3132 & 102971 \\
\hline 3 & Kukar & 20288 & 736550 & -43605 & 2705 & 120425 & 80695 & 9508 & 1680 & 11852 & 936739 \\
\hline 4 & Kutim & 5607 & 270153 & -3028 & 1162 & 57148 & 34733 & 8590 & -874 & 3475 & 376966 \\
\hline 5 & Berau & 6070 & 36614 & -31219 & 546 & 5095 & 35896 & 11312 & -140 & 3593 & 67766 \\
\hline 6 & Malinau & 2847 & 2426 & -23 & 147 & 3622 & 7599 & 341 & -4 & 774 & 17728 \\
\hline 7 & Bulungan & 3123 & 5278 & -20137 & 1223 & 367 & 16304 & 2897 & -27 & 2655 & 11682 \\
\hline 8 & Nunukan & 3808 & 16432 & -29 & 997 & 11633 & 9080 & 1409 & -15 & 1961 & 45276 \\
\hline 9 & Balikpapan & 3235 & 30502 & -498250 & 12050 & 185176 & 331037 & 62097 & 2871 & 15649 & 138625 \\
\hline 10 & Samarinda & 1822 & 13984 & -181733 & 20615 & 63968 & 185704 & 52708 & 8890 & 47614 & 195792 \\
\hline 11 & Tarakan & 1810 & 4055 & -15578 & 4142 & 10141 & 73714 & 9830 & $\overline{1508}$ & 2803 & 89408 \\
\hline 12 & Bontang & 316 & 1691 & $\begin{array}{l}- \\
2283450\end{array}$ & 1428 & 100988 & 40430 & 5424 & $\begin{array}{l}- \\
1074\end{array}$ & 3430 & $\begin{array}{l}- \\
2130818\end{array}$ \\
\hline 13 & PPU & 1804 & 170 & -187 & 415 & 3503 & 49420 & 885 & -288 & 1309 & 57031 \\
\hline
\end{tabular}

Tabel 5 di atas menunjukan bahwa sektor industri pengolahan dan sektor keuangan, persewaan dan jasa perusahaan memiliki PS negatif yang berarti pertumbuhan sektor-sektor ini lemah di tingkat propinsi. Sedangkan untuk sektor-sektor lainnya pertumbuhannya relatif cepat di tingkat propinsi.

Daya saing sektoral di masing-masing kabupaten/kota di Kalimantan Timur selama tahun 2002-2004 bervariatif dilihat dari nilai differential shift-nya (DS) dimana untuk 
Kabupaten Pasir daya saing sektor bangunan, sektor perdagangan, hotel dan restoran, sektor pengangkutan dan komunikasi serta sektor jasa masih lemah dibanding daerah lainnya.

Kabupaten Kubar hanya sektor pertanian yang daya saingnya lemah sedangkan sektor lainnya cukup kuat. Sektor pertanian cukup kuat daya saingnya di daerah PPU, Balikpapan dan Samarinda. Hampir di seluruh wilayah kabupaten/kota di Klaimantan Timur memiliki keuntungan lokasional yang baik di sektor industri pengolahan terutama Kota Samarinda dan Kota Balikpapan, sedangkan Kutai Timur cukup kuat pada sektor pertambangan dan penggalian. Sektor perdagangan, hotel dan restoran cukup kuat di Kota Samarinda dan Kota Tarakan, begitu pula sektor jasa yang cukup kuat di Kota Tarakan.

\section{Sektor Potensial}

Untuk penentuan di daerah mana masing-masing sektor terpilih lebih baik untuk dikembangkan dilakukan penggabungan analisis LQ, DS dan PS. Tujuan dari penentuan dan pemilihan lokasi yaitu agar efisiensi kegiatan ekonomi dapat lebih dimaksimumkan. Untuk itu melalui analisis-analisis tersebut disusun skala prioritas pembangunan sektoral di propinsi Kalimantan Timur.

Tabel 6.

Skala Prioritas Pembangunan Sektoral Kalimantan Timur Berdasar PDRBTahun 2002-2004 Atas Dasar Harga Konstan 2000

\begin{tabular}{|c|c|c|}
\hline PRIORITAS & SEKTOR & KABUPATEN / KOTA \\
\hline \multirow[t]{2}{*}{ I } & Pertanian & $\begin{array}{l}\text { Pasir, Kutai Kartanegara, } \\
\text { Tarakan, PPU }\end{array}$ \\
\hline & $\begin{array}{l}\text { Perdagangan, Hotel } \\
\text { dan Restoran }\end{array}$ & $\begin{array}{l}\text { Malinau, Samarinda } \\
\text { Tarakan }\end{array}$ \\
\hline \multirow[t]{5}{*}{ II } & Jasa & $\begin{array}{l}\text { Kutai Barat, Malinau, Bulungan, } \\
\text { Balikpapan, Tarakan, PPU }\end{array}$ \\
\hline & $\begin{array}{l}\text { Pertambangan dan } \\
\text { Penggalian }\end{array}$ & $\begin{array}{l}\text { Pasir, Kutai Barat, Kutai Timur, } \\
\text { Berau }\end{array}$ \\
\hline & $\begin{array}{l}\text { Listrik, Gas dan Air } \\
\text { Bersih }\end{array}$ & $\begin{array}{l}\text { Bulungan, Nunukan, Balikpapan, } \\
\text { Tarakan }\end{array}$ \\
\hline & Bangunan & $\begin{array}{l}\text { Kutai Barat, Malinau, Nunukan, } \\
\text { Samarinda, Tarakan }\end{array}$ \\
\hline & $\begin{array}{l}\text { Pengangkutan dan } \\
\text { Komunikasi }\end{array}$ & Bulungan, Samarinda, Tarakan \\
\hline
\end{tabular}




\begin{tabular}{|l|l|lc|}
\hline III & $\begin{array}{l}\text { Industri Pengolahan, } \\
\text { Keuangan, Persewaan } \\
\text { dan Jasa Perusahaan }\end{array}$ & $\begin{array}{l}\text { Balikpapan, Kutai } \\
\text { Samarinda, PPU }\end{array}$ & Barat, \\
\hline
\end{tabular}

Prioritas I, pembangunan sektoral di propinsi Kaltim (sektor basis, pertumbuhan cepat (LQ>1; PS>0) terdiri dari sektor pertanian, sektor perdagangan, hotel dan restoran, serta sektor jasa. Sektor-sektor tersebut akan dikembangkan di kabupaten/kota yang mempunyai angka LQ>1 dan DS >0. Sektor pertanian dikembangkan di kabupaten Pasir, Kutai Kartanegara, Kota Tarakan, serta Kabupaten PPU dengan Gerbang Sepadu-nya. Sektor perdagangan, hotel dan restoran lebih dikembangkan di Malinau, Samarinda dan Tarakan, sedangkan untuk sektor jasa lebih dikembangkan di Kutai Barat, Malinau, Bulungan, Balikpapan, Tarakan dan PPU.

Prioritas II, yang dipilih adalah sektor non basis namun memiliki tingkat pertumbuhan yang tinggi sehingga layak untuk dikembangkan. Sektor-sektor tersebut adalah sektor pertambangan dan penggalian, sektor listrik, gas dan air bersih, sektor bangunan dan sektor pengangkutan dan komunikasi. Sektor-sektor tersebut akan dikembangkan di kabupaten/kota yang mempunyai angka LQ $>1$ dan DS $>0$. Sektor Pertambangan dan penggalian dikembangkan di Kabupaten Pasir, Kutai Barat, Kutai Timur dan Berau. Sektor lainnya yang pembangunannya harus lebih dioptimalkan adalah sektor listrik, gas dan air bersih yang dikembangkan di Bulungan, Nunukan, Kota Balikpapan dan Kota Tarakan.

Sektor listrik, gas dan air bersih ini, dalam masa pembangunan dimana pertumbuhan akan permintaan (demand) semakin meningkat namun tidak dibarengi dengan meningkatnya pelayanan, yang disebabkan berbagai keterbatasan dan hambatan maka besarnya permintaan misalnya Balikpapan dengan menjamurnya pembangunan hotel-hotel mewah dan Samarinda dengan berbagai penawaran perumahan yang berarti permintaan akan sektor ini semakin besar namun ternyata pihak terkait tidak mampu memenuhi, justru mengarah pada pembebanan masyarakat, karena itu diupayakan kerjasama pemerintah dan terutama pihak terkait dalam mengatasi hambatan pada sektor ini karena permintaan akan sektor ini akan selalu meningkat.

Tentunya sangat disayangkan bila "hujan" investasi pada sektor lain seperti perhotelan di Balikpapan dan perumahan di Samarinda tersebut tidak dibarengi atau justru merugikan masyarakat karena sektor listrik tidak mampu memenuhi permintaan yang semakin besar. Untuk sektor bangunan sebaiknya prioritas lebih dikembangkan di Kabupaten Kutai Barat, Malinau, Nunukan, serta Kota Samarinda dan Kota Tarakan. Begitu pula dengan sektor pengangkutan dan komunikasi yang dikembangkan di Bulungan, Kota Samarinda dan Kota Tarakan.

Prioritas III, ditempati sektor industri pengolahan dan sektor keuangan, persewaan dan jasa perusahaan yang merupakan sektor non basis yang pertumbuhannya lambat. Meski merupakan sektor non basis dan pertumbuhannya lambat namun sektor industri pengolahan memberikan kontribusi yang sangat besar pada PDRB Kalimantan Timur, sehingga laiklah 
bila pengelolaannya diperhatikan. Sektor keuangan, persewaan dan jasa perusahaan juga sangat perlu dikembangkan terutama untuk mendukung sektor-sektor prioritas I dan II sehingga akselerasi pembangunan di Kalimantan Timur dapat berjalan dengan baik. Sektor industri pengolahan dikembangkan di Kota Balikpapan sedangkan sektor keuangan, persewaan dan jasa perusahaan akan dikembangkan di Kutai Barat, Kota Samarinda, dan PPU.

Jadi meskipun kontribusi sektor pertambangan dan penggalian serta sektor industri pengolahan sangat besar bagi propinsi Kalimantan Timur namun sektor tersebut bukan merupakan sektor basis secara keseluruhan. Sektor-sektor ini hanya basis pada sebagian kecil kabupaten/kota namun berpengaruh besar secara keseluruhan terhadap PDRB Kalimantan Timur dimana pertumbuhan kedua sektor ini juga termasuk lambat.

Peningkatan pendapatan daerah dengan prioritas sektor unggulan perlu didukung oleh pembangunan infrastruktur yang lebih banyak dan lebih lengkap di sebagian besar kabupaten/kota di Kalimantan Timur (terutama daerah yang memiliki laju pertumbuhan tinggi dengan PDRB per kapita yang masih kurang) dengan demikian diharapkan dapat memacu pertumbuhan ekonomi yang sekaligus diharapkan mampu mendorong investorinvestor lokal dan asing untuk masuk ke wilayah ini namun dalam upaya meningkatkan pendapatan daerah tersebut diketahui semakin maju perekonomian suatu daerah maka akan semakin banyak macam dan obyek pajak yang dapat dikenai pajak dan retribusi daerah. Bahkan dengan alasan untuk meningkatkan pendapatan daerah (PAD), pemerintah daerah menetapkan beberapa pungutan, pajak, sumbangan sukarela, dan pembatasan-pembatasan yang ditujukan kepada investor dan kegiatan bisnis yang mengakibatkan distorsi perdagangan dan tidak sesuai dengan UU No 34/2000. Banyaknya pajak yang dikenakan tentunya akan "menakuti" investor dalam menanamkan modal, oleh karenanya dengan didapatnya sektor potensial di daerah diharapkan alokasi dana pembangunan dapat lebih ditekankan pada peningkatan dan penarikan investor ke sektor potensial tersebut dan diupayakan agar pengenaan pajak tidak akan berdampak ekonomi negatif dalam arti tidak menyebabkan adanya alokasi faktor produksi yang salah dan menghambat pembangunan serta disesuaikan dengan syarat-syarat pajak dan retribusi lainnya namun dengan terus memberdayakan sektor lainnya. Diharapkan akan terjadi peningkatan pendapatan baik pada perseorangan maupun perusahaan (UMKM) yang nantinya akan meningkatkan konsumsi dan tabungan (saving) dan berarti daya beli masyarakat naik yang tentunya akan meningkatkan pajak, dan tentunya ini akan meningkatkan kapasitas anggaran daerah pada umumnya dan PAD pada khususnya.

\section{Catatan Penutup}

Kita ketahui bahwa migas sangat mendominasi nilai PDRB Kalimantan Timur namun bersifat tidak dapat diperbarui (non renewable) sehingga pembangunan dari sektor non migas harus lebih dioptimalkan. Penentuan sektor prioritas terutama dari non migas perlu dilakukan agar efisiensi pembangunan dapat dimaksimumkan disamping berusaha meningkatkan kualitas sumber daya manusianya sehingga dapat menjadi modal pembangunan daerah, yaitu dengan meningkatkan produktivitas dan profesionalisme sumberdaya manusianya sedangkan bagi kabupaten/kota yang tidak memiliki sumber daya alam harus terus dioptimalkan pembangunannya pada sektor non-SDA karena ada kecenderungan selama ini bahwa penerimaan daerah tergantung pada dana perimbangan dan subsidi pusat, karenanya sesuai 
dengan prioritas pembangunan Kalimantan Timur saat ini, diprioritaskan pembangunan sumber daya manusia yang dibarengi dengan pembangunan infrastruktur ekonomi terutama jalan dan jembatan, serta pembangunan pertanian dalam arti luas. Jadi dengan kata lain Kalimantan Timur harus berusaha mengurangi ketergantungannya akan keunggulan comparative yang dimiliki dan menjadikan sektor-sektor potensial sebagai keunggulan competitive yang dimiliki. Akselerasi ini tentunya akan dibarengi dengan terus dilakukannya pembangunan sarana prasarana pendukung terutama infrastruktur.

Percepatan pembangunan juga memerlukan penanaman modal oleh investor. Kepastian hukum dalam berusaha haruslah jelas disini, selain sektor potensial daerah dan kelengkapan sarana prasarana. Kebijakan-kebijakan daerah juga sebaiknya tidak mempersulit bahkan justru mempermudah para investor, seperti yang telah dilakukan pemerintah Tarakan dengan tax holiday untuk investasi jangka pendek, dimana hal ini dimaksudkan agar dalam jangka panjangnya akan menguntungkan karena dengan kebijakan ini akan banyak menarik investor sehingga multiplier effect-nya akan meningkatkan lapangan kerja dan kemudian meningkatkan employee yang akan berpengaruh pada peningkatan penghasilan dimana penerimaan daerah berpengaruh dari PPh dan PPn. Jadi disini hendaklah pemerintah daerah bertindak sebagai 'katalisator' dengan mengeluarkan kebijakan-kebijakan daerah yang 'menarik' yang akan memicu terjadinya multiplier effect pada berbagai sektor pembangunan di daerahnya.

\section{Daftar Kepustakaan}

Arsyad, Lincolin. 1999. Pengantar Perencanaan dan Pembangunan Ekonomi Daerah. Edisi Pertama. Yogyakarta: BPFE

Badan Pusat Statistik. 2005. Kalimantan Timur dalam Angka 2004/2005. BPS Kalimantan Timur

2004. PDRB Kabupaten/Kota Di Kalimantan Timur Menurut Lapangan Usaha, Tahun 2000-2004. BPS Kalimantan Timur

Glasson, Jhon. 1976. Pengantar Perencanaan Regional. Jakarta: Lembaga Penerbit FE UI

Jhingan, M.L. 1992. Perencanaan Pembangunan Ekonomi. Terjemahan. Jakarta: CV. Rajawali

Kadariah. 1978. Ekonomi Perencanaan. Jakarta: Lembaga Penerbit FE UI

Kaltim Post, Daya Mampu Listrik PLN Habis; Belasan Hotel Baru Bakal Gelap, 4 Agustus 2006

Senin, Imdad Berjuang Listrik Lagi; Ke Menteri ESDM, Berharap

Balikpapan Masuk Wilayah Krisis Listrik, 6 agustus 2006

Balikpapan Siap Bangun Pembangkit Listrik Berkekuatan 2 ×40 MW;

Listrik Ada Titik Terang, 26 Agustus 2006

Kartasasmita, Ginandjar. 1996. Pembangunan Untuk Rakyat: Memadukan Pertumbuhan dan Pemerataan. Jakarta: PT Pustaka Cidesindo 
Kuncoro, Mudrajad. 2004. Otonomi dan Pembangunan Daerah: Reformasi, Perencanaan, Strategi, dan Peluang. Jakarta: Penerbit Erlangga

Richardson, Harry. W. 1977. Dasar-Dasar Ilmu Ekonomi Regional. Terjemahan. Jakarta: Lembaga Penerbit FE UI

Sukirno, Sadono. 1976. Beberapa Aspek Dalam Persoalan Pembangunan Daerah. Jakarta: Lembaga Penerbit FE UI

.1980. Ekonomi Pembangunan: Proses,

Masalah, dan Dasar Kebijaksanaan. Jakarta: Lembaga Penerbit FE UI

Sumodiningrat, Gunawan. 1999. Pengembangan Wilayah. Jurnal Perencanaan Wilayah dan Kota. Vol. 10. No. 3. (November): 146-157

Suparmoko. 2001. Ekonomi Publik Untuk Keuangan \& Pembangunan Daerah. Edisi Pertama. Yogyakarta: Penerbit ANDI

Tambunan, Tulus. 1996. Perekonomian Indonesia. Jakarta: Ghalia Indonesia 2001. Transformasi Ekonomi di Indonesia: Teori dan Penemuan Empiris. Edisi Pertama. Jakarta: Salemba Empat 